Gotelind Müller, Documentary, World History, and National Power in the PRC: Global Rise in Chinese Eyes, London, New York, Routledge, 2013, XII+252 pp.

\title{
Yves Russell
}

Translator. Will Thornely

\section{(2) OpenEdition \\ 12 Journals}

\section{Electronic version}

URL: http://journals.openedition.org/chinaperspectives/6744

DOI: 10.4000/chinaperspectives.6744

ISSN: 1996-4617

\section{Publisher}

Centre d'étude français sur la Chine contemporaine

\section{Printed version}

Date of publication: 1 June 2015

Number of pages: 66-67

ISSN: 2070-3449

\section{Electronic reference}

Yves Russell, « Gotelind Müller, Documentary, World History, and National Power in the PRC: Global Rise in Chinese Eyes, ", China Perspectives [Online], 2015/2 | 2015, Online since 01 January 2017, connection on 23 September 2020. URL : http://journals.openedition.org/chinaperspectives/6744 ; DOI : https:// doi.org/10.4000/chinaperspectives.6744 
the city of Hong Kong, capturing "its heartbeat and its beauty." In Johnnie To's films, on the other hand, Hong Kong is a more tangible presence, and each feature film provides the film-maker with the opportunity to show several different faces of the territory.

Falin adopts two approaches in his book: the history of cinema in the two cities, and the study of how they are portrayed in film. Although the combination of these two approaches allows the many links between the two cities and their film-making to be approached in an original and complimentary manner, it also gives rise to a number of repetitions, especially in terms of film titles and historical facts, which ultimately weigh down the text. This is felt especially strongly in the first section of the work, in which the task of recounting the intertwined histories of the various film studios has led the author to make so many cross-references between the two cities and their film-making heritages that the pace of the narration is sometimes broken.

The second section, on the other hand, is far more fluid and effective; that said, while it is understandable that the author is not able to delve deeply into the various aspects of how the cities of Shanghai and Hong Kong are portrayed in film, it is unfortunate that certain fundamental films are not cited (such as Jacob Cheung's Cageman) or are only covered fleetingly (for example, I wish I knew, by Jia Zhangke) rather than being the subject of greater reflection and analysis.

The eighth chapter of the third and final section of the work also contains a few repetitions before offering portraits of the three major directors mentioned above (Lou Ye, Wong Kar-wai, and Johnnie To). Falin's analysis of the impact their film-making has had on the imaginary and social representation of the two cities is astute and pertinent.

An exhaustive and detailed bibliography concludes the work, and will doubtless prove very useful to any readers wishing to make their own contribution to research into relations between cities and film, an area that the author currently considers to be excessively "Eurocentric."

\section{Translated by Will Thornely.}

I Luisa Prudentino is professor of Chinese language and civilisation at the University of Salento (Lecce, Italy) and lecturer in history of Chinese cinema at INALCO (Paris, France), the University of Artois (Arras, France) and the University of Lorraine (Metz, France) (luisaprudentino@free.fr).

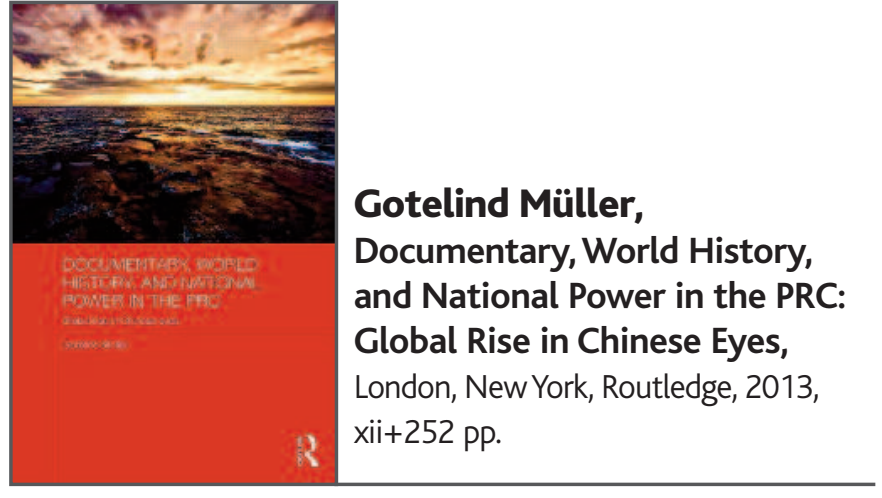

\section{YVES RUSSELL}

( otelind Müller has for a number of years been studying the formation of Chinese historical consciousness and, more specifically, the way in which conceptions of the national Self and the foreign Other are conveyed through representations of history. It was this research that led her to carry out a detailed analysis of Zou Xiang Gonghe (Towards the Republic), which was broadcast in 2003 on the state channel CCTV, and to then study the way in which foreign and, more particularly, European history have been covered in various academic curricula in China since 1900. (1)

In Documentary, World History, and National Power in the PRC, Müller returns to televisual analysis, studying three historical documentaries broadcast in multiple episodes in China between 2006 and 2007: Daguo jueqi 大 国崛起, Fuxing zhi lu 复兴之路, and Ju an si wei 居安思危, which she chose to translate into English respectively as The Rise of the Great Powers, The Road to Revival, and Alert to Danger while Dwelling in Safety.

The author argues convincingly that by studying these three documentaries produced by state institutions, it becomes possible to grasp "the ways in which the Chinese officially favoured view of history is transmitted via the media so as to guide perceptions of foreign and Chinese history towards legitimization of PRC policies" (p. 4). It can be seen that the author views the documentaries as three moves made by the Chinese state in the same game in order to legitimise its political agenda. By focusing on the rise of nine "great nations" (daguo 大国) - Spain, Portugal, the Netherlands, Great Britain, France, Germany, Japan, Russia, and the United States - since the fifteenth century, Daguo jueqi shows that "What is to be learned from history is therefore only what a country needs in order to 'rise'" (p. 8). Fuxing zhi lu recounts the history of China since 1840 from the perspective of its "revival," allowing China to be tied in with the history of the great nations while setting it apart. Ju an si wei, whose full title is "Alert to Danger while Dwelling in Safety: The historical lesson of the perishing of the Soviet Communist Party" (Ju an si wei - Sugong wangdang de lishi jiaoxun 居安思危 一 苏共亡党的历史教训), shows what China (or rather the CCP) needs to avoid (p. 8).

One could quibble endlessly on the choice of these three documentaries or even on the influence of the documentary format on the popular historical consciousness. In the introduction (Chapter One), Müller justifies her choice by pointing to the increasing success of the documentary format with the Chinese public, and in particular the aura of objectivity and scientificity it enjoys (p. 1). The three documentaries studied also allow three 
sub-genres telling of the use of this format by the single-party state to be addressed: the "historical documentary" (lishi jilu pian 历史纪录片 or lishi wenxian pian 历史文献片) in the case of Daguo jueqi, the "political edification" documentary (zhenglun pian 政论片) for Fuxing zhi lu, and the "reference document" (cankao pian 参考片) for Ju an si wei. In this way, "we can see the whole range of functions connected to 'official' documentary: to document, to transmit political views, and to educate" (p. 14).

One of the important contributions of Müller's work lies in the light it sheds on the origin and conception of the three documentary series. The three chapters (out of five, including an introductory chapter) given over to the analysis of the three series, episode by episode, account for 150 of the 200 pages of the study. The process of creating the three documentary series, by bringing together the academic, political, and media worlds in collaboration, is fascinating and well documented. This is particularly true of Daguo jueqi and Fuxing zhi lu, two projects that are part of a political discourse thought through at the highest levels of power. The narrative, musical, and indeed symbolic (colours, themes, etc.) analysis of the documentaries also reveals the use of a production style that aims, with varying degrees of subtlety, to promote the world view of the current political agenda, and of a style of narration that is controlled and adapted to the different target audiences. Müller shows the "legitimisation strategies" implemented by the CCTV producers, such as the use of "expert commentaries," in particular from foreign contributors. At the same time, she also shows that the apparent plurality of voices in Daguo jueqi is no more than window dressing: the authors remain in control of the narrative through the way in which it is produced (editing, cuts, soundtrack, etc.). The interviews merely legitimise and punctuate a script written in advance, and Müller mocks the clumsy truncating of certain interviews conducted in foreign languages, such as that with former French president Giscard d'Estaing. In Ju an si wei, on the other hand, the amusement is provided by the soundtrack. While leaders with a "positive" image (Lenin, Stalin) are associated with popular Russian songs or marches, those with a "negative" image (Khrushchev, Brezhnev, and in particular Gorbachev) are associated with gloomy or disturbing music, often taken from American blockbusters. Moving beyond the realm of anecdotes, there is evidence of expert use of the "unnoticed instrument of narrational manipulation" (an expression Müller borrows from W. Guynn), which serves to legitimise a discourse whose aim is to reinforce and modify opinions about China and foreign countries in the manner desired by the elites in power.

In the fifth and final chapter, entitled "Framing visions of China and the world - The state, documentary and history in contemporary perspective," Müller refers - among other things - to theories pertaining to historical narrative (Ricœur, etc.) and the media (Rosenstone, Nichols, Guynn, etc.) in order to position the role of the three documentaries studied in a comparative and global perspective. The use and appropriation of the documentary format by the Chinese state are linked to the changing demands of an increasingly exacting and critical Chinese public, which is not so easily satisfied by conventional propaganda films. Daguo juegi is a response to this expectation of "truth" and "authenticity" held by Chinese viewers who are more educated and have a more open world view, and are consequently prepared to challenge the official version of history. However, although in terms of its form this documentary (like Fuxing zhi lu) appears to be "designed in a less 'dogmatic' and more 'polyphonic' way than [it] used to be during Mao's life time" (p. 180), the editing and controlled, pre-planned narration help ensure the uniformity of the official line. This is conveyed by re- peating stereotyped and "fetishised images," which help construct a national collective memory and reinforce "prefigured" views of history (p. 184). These stereotypes echo those transmitted in schools and by other television productions (soap operas, films, etc.).

However, this final chapter, while being of interest in terms of offering a theoretical and comparative perspective, is not satisfactory as a concluding chapter. For more coherence, it could have been positioned after the introduction and before the detailed analysis of the three documentaries. This would have emphasised the need for a genuine conclusion that could have been an analysis summarising the ability of the Chinese state to use different formats (documentaries, series, books, etc.) and vehicles (media, education, etc.) to impose and standardise a conception and role of history. Moreover, the historian Zi Zhongyun, cited by Müller and appearing in Daguo jueqi, observes that the conception of "history as a mirror" (yishi weijian 以史为鉴) imposes a memory-based and patriotic relationship with the past that serves to keep the ruling dynasty in power. (2)

Müller has scattered the book with links between the history told in the documentaries and the history taught in schools, making the most of her previous line of study. These references could also have been summarised and systematised in order to emphasise the continuities and discontinuities of the historiographical narrative of the Chinese state. The author underlines how these documentaries also have the function of "updating" the official historiography, while school textbooks are only published and replaced at a much slower rate. This holds particularly true given that episodes of Daguo jueqi and Fuxing zhi lu are sometimes screened in class in order to illustrate the lesson, as I was able to confirm when interviewing junior high school teachers.

In terms of form, while the many notes and bibliographical references are to be applauded, a list of the people interviewed in Daguo jueqi and Fuxing zhi lu would not have gone amiss. The bibliography would also have benefitted from being organised by theme, with the 26 pages of references thus bringing together not only works on the emergence of China, media theory, and collective memory, but also references to blogs or commentaries on the three documentaries studied.

In conclusion, Müller's work sheds an interesting light on the use of the documentary format by the Chinese state as a vehicle for collective historical representations, and also offers a rich and detailed analysis of three documentaries that have different narrative forms but share the same intention. However, it is unfortunate that this study, which is the outcome of a project carried out with students in a research programme (in this case the "Cluster of Excellence" of Heidelberg University), does not offer a summary of the various projects undertaken by Müller concerning the representation of history on the television and at school. The wait goes on for such a synthesis, which would surely be extremely interesting and fruitful.

I Translated by Will Thornely.

I Yves Russell is a PhD student in history and civilisation at EHESS

(School for Advanced Studies in Social Sciences), Paris

(yvesrussell@gmail.com).

2. Zi Zhongyun, "Gexin Zhongguo chuantong lishiguan" (Reforming the conception of the traditional history of China), Yanhuang Chunqiu, No. 7, 2014, pp. 5-9. Also available online at www.yhcqw.com/html/yjy/2014/77/3845.html (accessed on 21 April 2015). 